\title{
Cidadãos e Concidadãos nos Discursos de Posse da Primeira República
}

\author{
Citoyens et Concitoyens dans les Discours Inauguraux DeS \\ Présidents de la Première République
}

\section{Sheila ELIAS DE OLIVEIRA*}

Resumo: Este artigo apresenta uma análise semântico-enunciativa das palavras cidadão(s) e concidadãos nos discursos de posse dos presidentes da Primeira República Brasileira. Fundamentada na Semântica do Acontecimento, a autora se pergunta como significa, nos acontecimentos dos discursos de posse dos presidentes da Primeira República, a enunciação de cidadão(s) e concidadãos, e busca respondê-la pelo modo como, por meio dessas palavras, se afirma a relação entre governante e governados, e o pertencimento do governo que se inicia ao regime republicano. Dando visibilidade às diferenças na enunciação das palavras-objeto entre os presidentes do período estudado, ela advoga que a instabilidade, no Brasil, dessas palavras-chave nas Repúblicas Ocidentais Modernas, é uma especificidade de sua semântica no nosso português, ligada ao modo como se inscrevem na República brasileira, e defende a necessidade investigar as particularidades dos seus sentidos na enunciação dos diferentes governantes para compreender o modo como, por meio dessas palavras, cada governo afirma seu pertencimento ao regime republicano, e o modo como estas palavras vão se movimento semanticamente entre a instabilidade e a estabilidade.

Palavras-chave: Sentido. Enunciação. Palavras republicanas.

Résumé: Cet article présente une analyse sémantique-énonciative des mots citoyen $(\mathrm{s})$ et concitoyens dans les discours inauguraux des présidents de la Première République brésilienne. Fondée sur la Sémantique de l'événement, l'auteur se demande comment signifie, dans les événements des discours inauguraux

* Doutorado em Linguística na Universidade Estadual de Campinas. Professora de Semântica e Pragmática no Departamento de Linguística do Instituto de Estudos da Linguagem da Universidade Estadual de Campinas. Contato: sheilaelias@yahoo.com. 
des présidents de la Première République, l'énonciation de citoyen (s) et concitoyens. Elle cherche à y répondre en observant la manière dont, à travers ces mots, la relation entre gouvernants et gouvernés est affirmée, ainsi que l'appartenance du gouvernement qui commence au régime républicain. Donnant de la visibilité aux différences dans l'énonciation des mots-objet entre les présidents de la période étudiée, elle soutient que l'instabilité au Brésil des ces mots-clés dans les modernes républiques occidentales est une spécificité de sa sémantique dans le portugais du Brésil, liée à la façon dont ils s’inscrivent dans la République brésilienne, et fait valoir la nécessité de rechercher sur les particularités de leurs sens dans l'énonciation des différents gouvernants pour comprendre comment, à travers ces mots, chaque gouvernement affirme son appartenance au régime républicain, et comment ces mots glissent sémantiquement entre stabilité et instabilité.

Mots-clés: Sens. Énonciation. Mots républicains.

\section{Palavras Republicanas}

A palavra cidadão, derivada do latim, sofre uma mudança de sentido na modernidade a partir da relação com o seu equivalente por tradução no francês - citoyen, que, com a Revolução Francesa e o processo de instauração do regime republicano, deixa de significar aquele que tem privilégios na cidade (sentido este que tem sua origem na Antiguidade Clássica), e passa a significar todo indivíduo na relação com o Estado, pela igualdade de direitos e deveres. Em trabalho anterior (ELIAS DE OLIVEIRA, 2006) mostramos, em dicionários do português, esses movimentos na semântica de cidadão, que resultam no início do século XX na derivação de cidadania, de modo semelhante aos movimentos pelos quais no francês, no século XVIII, a partir de citoyen, deriva-se citoyenneté, da qual cidadania é equivalente.

Entretanto, se os movimentos de cidadão que resultam no surgimento de cidadania parecem espelhar a mudança em citoyen que resulta em citoyenneté, o que pudemos atestar nos dicionários brasileiros ao longo do século XX (nosso primeiro dicionário geral de língua portuguesa é de 1938), é uma especificidade em relação à representação lexicográfica dessas palavras em francês: no verbete cidadão, há uma diluição do sentido político nos discursos jurídico e urbano, em acepções como "habitante da cidade" e "indivíduo no gozo dos direitos civis e políticos de um Estado"; já no verbete cidadania 
não há sequer uma definição própria, mas um reenvio a cidadão por acepções como "qualidade de cidadão" ou "qualidade ou estado de cidadão".

É nos dois dicionários publicados no século XXI - o Dicionário Houaiss da Língua Portuguesa (2001) e o Dicionário de Usos do Português (2002), que começamos a ter definições próprias no verbete cidadania. Elas vêm acompanhadas de alterações no verbete cidadão. Estes dois movimentos, juntos, sinalizam um novo momento da enunciação dessas palavras no Brasil, momento este no qual os verbetes lexicográficos representam uma diferença na semântica das duas palavras, inscrita no modo de interpretação do próprio radical: cidadania aparece predicada por elementos que significam direitos; cidadão por elementos que significam tanto direitos quanto deveres. Se esta é uma especialização em curso, ou se é uma tendência que conviverá com a atribuição de direitos e deveres às duas palavras, é uma questão a se responder com o tempo.

Os dicionários, que constituem um corpus privilegiado para a observação da história das palavras, nos permitiram apreender a relação complexa entre estas palavras de línguas diferentes - citoyen/ citoyennetée cidadão/ cidadania: se, por um lado, há uma ligação formal e semântica entre elas pela derivação comum do latim, e pela própria relação entre as línguas neolatinas e seus povos, por outro lado, suas histórias de enunciações fazem com que ideologicamente os sentidos deslizem para direções distintas e, politicamente, elas trabalhem diferentemente na afirmação da relação entre o sujeito e o Estado.

$\mathrm{Na}$ análise que aqui propomos, buscamos, fundamentados na Semântica do Acontecimento, dar um pequeno passo adiante na compreensão dos sentidos de cidadão e cidadania no português do Brasil republicano; mais especificamente, no período de instauração da República, a que a história oficial se refere como Primeira República ou República Velha: de 1889, ano da Proclamação, até 1930, ano em que Getúlio Vargas assume o poder, com a chamada Revolução de 1930.

Os presidentes deste período são onze: Deodoro da Fonseca (18891891); Floriano Peixoto (1891-1894); Prudente de Morais (1894-1898); Campos Sales (1898-1902); Rodrigues Alves (1902-1906); Afonso Pena (1906-1909); Hermes da Fonseca (1910-1914); Venceslau Brás (1914-1918); Epitácio Pessoa (1919-1922); Artur Bernardes (1922-1926); e Washington Luís (1926-1930). Tomamos como corpus os seus discursos de posse. Estes têm uma especificidade que nos interessa: eles anunciam um programa de 
governo e inauguram um modo de referência do novo governante aos seus governados. As palavras presentes no seu acontecimento enunciativo têm a força de projetar um futuro de interpretações sobre o governo que se inicia.

Nos discursos de posse de Venceslau Brás, Artur Bernardes e Washington Luís, não há nenhuma ocorrência de cidadão ou de seus derivados. Nos discursos dos outros oito presidentes, encontramos ocorrências de concidadãos (sempre como substantivo e no plural) e de cidadão/cidadãos (sempre como substantivos). É sobre os discursos em que as palavras aparecem que iremos trabalhar, ainda que entendamos que, nos modos de significar destas formas, está em questão a relação com os outros discursos de posse em que elas não aparecem, sobre os quais podemos nos perguntar que outras palavras aparecem em seu lugar. Está em questão também a ausência de cidadã $(s)$ e, particularmente, de cidadania, palavra da República Moderna, ambas derivadas de cidadão. A ausência de cidadania é sintomática da instabilidade da relação ente cidadão/cidadãos/concidadãos que observaremos nos textos do corpus.

A forma feminina cidadã(s), seja como adjetivo ou substantivo só aparecerá nos discursos de posse na Nova República: no primeiro discurso de posse de Fernando Henrique Cardoso (1995), como adjetivo singular, em "reivindicação cidadã"; e no primeiro discurso de posse de Lula (2003), como substantivo, tanto no singular como no plural, sempre se referindo ao conjunto da população, ao lado de cidadão ou cidadãos: "cidadão(s) e cidadã(s)".

Embora cidadania, em seu primeiro registro lexicográfico, tenha sido marcada como brasileirismo (em 1913, na terceira edição do Dicionário da Lingua Portuguesa, do português Cândido de Figueiredo), ela também só aparecerá nos discursos de posse na Nova República. A primeira ocorrência é em 1990, no discurso de posse de Fernando Collor de Mello, em que é enunciada como um dos dois "grandes temas" do seu programa, ao lado de democracia. Esta união representa, segundo ele, "o triunfo da ideia republicana”. Ainda assim, ela não se manterá presente em todos os discursos de posse subsequentes, o que nos leva a crer que a "ideia republicana", tal como presente no discurso de Collor, não triunfou. Afinal, que sentidos vão constituindo a palavra República na política de Estado brasileira, no seu modo de apropriação da "ideia republicana" advinda da Revolução Francesa? E de que modo a enunciação de cidadão e seus derivados produz uma determinação sobre República, ao afirmar a relação entre o brasileiro e o Estado? 
O discurso de Collor mostra que a relação entre cidadania, democracia e República, um século após a Proclamação da República, ainda precisa ser afirmada. Esta necessidade, sobretudo no que diz respeito à democracia, está certamente ligada ao fato de que este discurso é o primeiro de um presidente eleito pelo voto popular depois de mais de vinte anos de ditadura militar (1964-1985). Isto poderia levar a supor que a presença tímida de cidadão e seus derivados na enunciação do Estado se deve às duas ditaduras (Estado Novo e Ditadura Militar). Não é esta a nossa hipótese, mas sim de que o modo como essas palavras significam nos momentos democráticos é tão importante neste processo quanto o modo como significam nos períodos ditatoriais ${ }^{1}$. Sintomático disto é que, mesmo depois de Collor e seu discurso centrado na cidadania, nem esta palavra, ou tampouco cidadão e seus derivados, se mantém em todos os discursos de posse que se seguiram. $\mathrm{O}$ ir e vir destas palavras republicanas indica sua instabilidade na República brasileira. São estes sentidos instáveis que buscamos compreender, aqui dirigindo o foco sobre a Primeira República.

\section{Uma Semântica Enunciativa}

A Semântica do Acontecimento é uma semântica enunciativa de base materialista. Como tal, considera que o sentido deve ser compreendido a partir da enunciação, e que a enunciação é um acontecimento político. $\mathrm{O}$ acontecimento é definido como "diferença na sua própria ordem" (GUIMARÃES, 2002, p. 12). A diferença na enunciação se faz a partir da temporalização: o acontecimento instaura uma temporalidade que não é cronológica, mas simbólica.

Inscrito no interdiscurso, memória ideológica de sentidos ${ }^{2}$, o acontecimento enunciativo configura o seu presente pela rememoração de

${ }^{1}$ Para uma análise de cidadão na enunciação dos governantes da ditadura militar, ver Indursky (1996). As poucas ocorrências da palavra conduzem a autora a uma análise do nós tal como empregado por estes governantes, pela qual dá visibilidade a uma redistribuição dos direitos e deveres, que está na base do apagamento discursivo do cidadão.

2 A memória interdiscursiva ou interdiscurso é compreendida como o conjunto do dizível historicamente constituído, tal como a define a Análise do Discurso (AD) de linha francesa (PÊCHEUX, 1975; ORLANDI, 1996). Esta memória se atualiza e se refaz na relação entre discursos, entendidos como "efeitos de sentidos entre locutores", produzidos na enunciação (ORLANDI, 1996, p. 38). 
um passado de enunciações (os memoráveis), a partir dos quais projeta um futuro de interpretação. Este movimento é político. O político (ou a política) na enunciação é caracterizado "pela contradição de uma normatividade que estabelece (desigualmente) uma divisão do real e a afirmação de pertencimento dos que não estão incluídos" (GUIMARÃES, 2002, p. 16).

Ao analisar palavras do domínio político, e mobilizar, para analisá-las, uma concepção do dizer como político, operamos com dois sentidos de política(o): um que diz respeito à terminologia das Ciências Políticas e/ou do ideário político e que chega ao senso comum. Outro que diz respeito a um conceito da teoria enunciativa que mobilizamos. Assim, no primeiro sentido, este conjunto de palavras é entendido como políticas na medida em que são ligadas à terminologia da organização do Estado e da governança, e em que são enunciadas por políticos, ou seja, por pessoas engajadas em (tendo-os já assumido ou não) cargos legislativos ou executivos. Por sua vez, no segundo sentido, nelas observamos o movimento político enunciativo, inscrito na divisão desigual entre línguas e falantes. Nos perguntamos como significa, nos acontecimentos dos discursos de posse dos presidentes da Primeira República, a enunciação da forma linguística cidadão e seus derivados. Procuramos compreender de que modo por meio dessas palavras se afirma a relação entre governante e governados, e o pertencimento do governo que se inicia ao regime republicano.

Estas questões nos guiarão para compreender o que cidadão/ cidadãos e concidadãos designam ao longo do corpus. A designação é entendida como a significação de um nome enquanto "uma relação linguística (simbólica) remetida ao real, exposta ao real, ou seja, enquanto uma relação tomada na história" (GUIMARÃES, 2002, p. 9). Não se trata da atribuição de um sentido fixo ou único, mas da compreensão do modo como o presente do acontecimento trabalha sobre a latência de significação da palavra, repetindo e/ou deslocando sentidos, e de que modo.

Concebendo os discursos de posse como textos, observaremos a designação das palavras-objeto pela sua relação com outras palavras em dois procedimentos de textualidade: a reescritura e a articulação. A reescritura(cão), conforme Guimarães (2007, p. 84), “é o procedimento pelo qual a enunciação de um texto rediz insistentemente o que já foi dito, fazendo interpretar uma forma como diferente de si". Ela é concebida nas relações intra e intertextuais, e é nesses dois movimentos que será levada em conta em nosso corpus. Por sua vez, a articulação diz respeito às relações de 
contiguidade locais que, não redizendo, afetam as expressões linguísticas no interior dos enunciados ou na relação entre eles (GUIMARÃES, 2007, p. 88). Estes dois procedimentos textuais - a reescritura e a articulação - nos permitem observar as determinações semânticas das palavras estudadas ao longo dos textos.

Vamos apresentar os recortes de cada um dos discursos de posse em que aparecem nossas palavras-objeto ${ }^{3}$. Neles, observaremos as determinações diretas e indiretas das palavras-objeto, a partir dos processos de reescrituração e articulação que incidem sobre elas, fazendo significar a relação entre os sujeitos do país e a República.

\section{Que Cidadão(s) e Concidadãos na Primeira República?}

Nos discursos de posse dos presidentes da Primeira República, encontramos duas palavras: cidadão(s) e concidadãos. Vejamos como as define o Dicionário da Lingua Portuguesa de Cândido de Figueiredo na edição de 1913: cidadão: " $m$. Morador de uma cidade. Aquelle que está no gôzo dos direitos civis e políticos de um Estado". (CANDIDO DE FIGUEIREDO, 1913, p. 468); concidadão " $m$. indivíduo que, em relação a outro ou outros, é da mesma cidade ou do mesmo país. (De con... + cidadão)" (CANDIDO DE FIGUEIREDO, 1913, p. 517).

De um lado, o dicionário lusitano afirma a derivação de concidadão a partir de cidadão; de outro, no enunciado definidor, ele não retoma a palavra cidadão, substituindo-a por "pessoa" e, a partir daí, indicando o que se partilha (significando no prefixo con-) indica. Nesta indicação, o sentido desliza, em relação à cidadão, da atribuição de direitos em relação ao Estado para a partilha de um espaço geopolítico: o país ou a cidade. Assim como se partilha o espaço da cidade (da qual o cidadão é morador), se partilha o do país.

Percebemos, então, que, na própria enunciação do Dicionário, nuances de significação identificam diferentemente o cidadão e o concidadão. Vejamos como isto se dá nos discursos de posse dos presidentes da Primeira República.

3 O recorte é entendido como um "fragmento do acontecimento da enunciação" (GUIMARÃES, 2011, p. 44). Esta noção é apropriada pelo autor a partir da sua definição na AD como "unidade discursiva", isto é, "fragmentos correlacionados de linguagem-e-situação” (ORLANDI, 1984, apud GUIMARÃES, 2011, p. 44). 


\subsection{A Proclamação da República: Deodoro da Fonseca (1889-1991)}

No discurso da Proclamação da República, Deodoro se dirige à população do país como seus "concidadãos". Esta palavra funciona como vocativo, e inicia enunciados em que se anuncia a nova ordem política que o acontecimento enunciativo da Proclamação instaura. O vocativo significa os alocutários-governados pela igualdade em relação ao locutor-governante; esta igualdade é, no entanto, desfeita pelas divisões dos concidadãos que significam nas suas articulações. No primeiro recorte, a divisão se dá em "o povo, o exército e a armada nacional", e "os cidadãos residentes nas províncias". Uns se separam dos outros como categorias sociais distintas; o "povo" se distingue dos "cidadãos residentes nas províncias", e ambos se distinguem do "exército" e da "armada nacional". O povo que proclama a República é o da capital do país, e o faz ao lado de duas categorias sociais em destaque: "o Exército e a armada nacional"'. Se a reescritura faz significar a disparidade entre povo e outras categorias sociais, a articulação significa a República proclamada como "a extinção do sistema monárquico representativo", o que se dá pelo decreto da "deposição da dinastia imperial" "em perfeita comunhão de sentimentos com os nossos concidadãos residentes na província" pelo "povo, o exército e a armada nacional”. A República é, portanto, enunciada como um movimento sem conflito, desejado pelos cidadãos de todo o território, e como um gesto não de instauração de uma nova ordem, mas de deposição de um regime: a dinastia imperial. Eis o recorte ${ }^{5}$ :

1. Concidadãos - $\mathrm{O}$ povo, o exército e a armada nacional, em perfeita comunhão de sentimentos com os nossos concidadãos residentes nas províncias, acabam de decretar a deposição da dinastia imperial e consequentemente a extinção do sistema monárquico representativo.

${ }^{4}$ Lembro o trabalho de Guimarães (1996) comparando os sentidos de cidadão no Império e na República, no qual ele dá visibilidade, no discurso da Proclamação da República, à desmontagem da performatividade da Proclamação no interior da relação de cidadania, apesar do emprego do vocativo concidadãos pelo Marechal Deodoro. A performatividade se dá em uma relação hierárquica entre Forças Armadas e povo.

5 Os textos dos discursos de posse foram retirados do site da presidência da República. Disponíveis em: < http://www.planalto.gov.br/infger_07/presidentes/gale.htm>. 
No recorte seguinte, o "governo provisório" se destaca dos "concidadãos", e é reescriturado por "simples agente temporário da soberania nacional" e por "governo da paz, da liberdade, da fraternidade e da ordem". É assim que, neste governo militar, "o exército e a armada nacional" se distinguem do "povo" como governantes e governados e concidadãos, referindo-se a ambos, significa esta disparidade. No recorte, mais uma vez, a República é enunciada como sem conflito, já que o "governo provisório" se afirma pela "paz" e pela "fraternidade". Claro, não sem o valor positivista tão cultivado nas Forças Armadas: a "ordem".

A República no Brasil, no discurso do seu proclamador, não significa em relação à luta armada, como na França; não significa nem mesmo em relação à luta, e sim a uma "plena comunhão de sentimentos", como vimos no recorte 1. "Liberdade", palavra-chave na Revolução Francesa, aqui assume o sentido de uma soberania pacificamente conquistada e é neste pacifismo que se inscreve o vocativo "concidadãos".

2. Concidadãos - O governo provisório, simples agente temporário da soberania nacional, é o governo da paz, da liberdade, da fraternidade e da ordem.

No terceiro recorte, destacam-se entre os "concidadãos" as "pessoas" (por reescritura, "cada funcionário") ligadas à "justiça ordinária” e à "administração civil e militar". Contraditoriamente à proclamação de um novo sistema de governo, a articulação a essas reescrituras vai produzindo um discurso de manutenção das estruturas administrativas/governamentais, o que produz um efeito de continuidade, e não de deslocamento político sobre "concidadãos".

3. Concidadãos - As funções da justiça ordinária, bem como as funções da administração civil e militar, continuarão a ser exercidas pelos órgãos até aqui existentes, com relação aos atos na plenitude dos seus efeitos; com relação às pessoas, respeitadas as vantagens e os direitos adquiridos por cada funcionário.

A direção de continuidade se reafirma no recorte 4, em que o "governo provisório" comunica aos "concidadãos" o reconhecimento e acatamento de "todos os compromissos contraídos durante o regime anterior", aí 
incluídos tratados com "potências estrangeiras", "dívida pública interna e externa", "contratos vigentes" e "mais obrigações legalmente estatuídas". O novo sistema não se define por um deslocamento político-administrativo em relação ao anterior. A relação com os outros Estados tampouco significa pela luta, e sim pela conciliação.

4. Concidadãos - O governo provisório reconhece e acata todos os compromissos nacionais contraídos durante o regime anterior, os tratados subsistentes com as potencias estrangeiras, a dívida pública externa e interna, os contratos vigentes e mais obrigações legalmente estatuídas.

Além das quatro ocorrências de "concidadãos", há, no discurso de posse de Deodoro, duas ocorrências de "cidadãos". A primeira se refere a todos os cidadãos da República, a quem o "governo provisório" garantirá "liberdade e direitos". Na articulação a "cidadãos", a proclamação da República é predicada como "revolução nacional, de caráter essencialmente patriótico". Uma "revolução" que, além de ser enunciada como patriótica, é, também, como vimos, enunciada como realizada sob um governo pacífico, fraterno e ordeiro.

5. Como resultado imediato desta revolução nacional, de caráter essencialmente patriótico, acaba de ser instituído um governo provisório, cuja principal missão é garantir, com a ordem pública, a liberdade e os direitos dos cidadãos.

Finalmente, o recorte 6 traz a segunda ocorrência de "cidadãos". Desta vez, não são referidos todos os "cidadãos", mas aqueles "abaixo-assinados", nomeados pelo chefe do poder executivo da nação para compor o governo provisório, "enquanto a nação soberana, pelos seus órgãos competentes, não proceder à escolha do governo definitivo". Estes governarão; aos governados, como "nação soberana", é atribuído o direito de escolha dos seus governantes, ainda que esta escolha seja indireta - "pelos seus órgãos competentes".

6. Para comporem esse governo, enquanto a nação soberana, pelos seus órgãos competentes, não proceder à escolha do governo 
definitivo, foram nomeados pelo chefe do poder executivo da nação os cidadãos abaixo assinados.

\subsection{A República garantida pelas armas: Floriano Peixoto (1891-1894)}

No discurso de posse de Floriano Peixoto, não aparece a palavra "concidadãos" e a única ocorrência de "cidadãos" não se refere a todos os governados, e sim à parcela "de diversas classes" que tomou as armas para "o restabelecimento da Constituição e das leis suspensas" pelo decreto de Deodoro da Fonseca que havia dissolvido a Constituição promulgada no mesmo ano. Estes "cidadãos", segundo as palavras do vice-presidente que acaba de tomar o poder como mandatário da nação, se juntam à "armada" e à "grande parte do exército", que, juntos, compõem "as classes armadas do país em prol da lei”. O pacifismo presente na enunciação da Proclamação é substituído pela afirmação da luta armada como elemento essencial para "defender e garantir a ordem e as instituições republicanas no interior do país".

7. A armada, grande parte do exercito e cidadãos de diversas classes promoveram pelas armas o restabelecimento da Constituição e das leis suspensas pelo decreto de 3 deste mês, que dissolveu o Congresso Nacional. A história registrará esse feito cívico das classes armadas do País em prol da lei, que não pode ser substituída pela força; mas ela registrará igualmente o ato de abnegação e patriotismo do generalíssimo Manoel Deodoro da Fonseca resignando o poder a fim de poupar a luta entre irmãos, o derramamento do sangue de brasileiros, o choque entre os seus companheiros de armas, fatores gloriosos do imortal movimento de 15 de novembro, destinados a defender, unidos, a honra nacional e a integridade da pátria contra o estrangeiro e a defender e garantir a ordem e as instituições republicanas no interior do País.

\subsection{O primeiro presidente eleito por voto direto: Prudente de Moraes (1894-1898)}

Em Prudente de Moraes, há uma ocorrência de "concidadãos" e 
outra de "cidadãos". "Concidadãos" se refere a todos os governados e vem precedida do especificador "meus": "meus concidadãos"; já "cidadãos" vem especificada por "dos mais ilustrados e competentes", e se refere aos que governarão junto com o presidente. A referência aos "concidadãos" se articula ao rememorado das eleições como "extraordinária prova de confiança" e da responsabilidade do cargo, assumido, segundo o presidente, por "imperioso dever patriótico" apesar de julgá-lo "muito superior" às suas forças. A referência aos "cidadãos dos mais ilustrados e competentes" se articula ao rememorado a "cooperação patriótica" destes e do apoio da "nação" ao presidente em sua "árdua missão", da qual ele avalia bem "os grandes embaraços e dificuldades de toda ordem", e a qual refere à particularidade da "atual situação". Se o que está em questão nas reescrituras e articulações às palavras-objeto não é mais afirmar o modo pacífico ou armado com que a República se estabelece, mas o voto direto como instrumento republicano democrático, um conflito, assim como em Floriano Peixoto, em oposição ao caráter pacífico da Proclamação, está posto. Em Prudente de Moraes, em um rememorado de dificuldades e sacrifício do presidente e de apoio patriótico "de toda a nação". Este rememorado marca a relação entre governante e governados como entre sacrificado e apoiadores, atribuindo o enfrentamento da crise indicada somente ao presidente - como se os governados não vivessem os efeitos da crise e não tivessem que ser apoiados ou como se não fossem sacrificados. É neste rememorado que se inscreve a enunciação de "cidadãos" e "concidadãos" no discurso do primeiro presidente civil.

8. Aceitando este elevado cargo, que não pretendi por julgá-lo muito superior ás minhas forças, especialmente na atual situação, submetome a imperioso dever patriótico, e não pouparei esforços nem sacrifícios para corresponder á extraordinária prova de confiança de meus concidadãos, manifestada de modo inequívoco no pleito eleitoral mais notável da vida nacional.

9. Conheço e avalio bem os grandes embaraços e dificuldades de toda a ordem com que terei de lutar no desempenho de minha árdua missão; - desanimaria, se não me sentisse apoiado pela nação e se não contasse com a cooperação patriótica de cidadãos dos mais ilustrados e competentes. 


\subsection{Os "altos destinos da nação" no discurso de posse de Campos Sales (1898-1902)}

No discurso de posse do segundo presidente civil da República, Campos Sales, há uma ocorrência de "concidadãos", que se refere a todos os governados, também especificada por "meus", como no discurso do antecessor, e a primeira ocorrência da forma singular cidadão, especificado por "eminente", referindo-se ao seu antecessor, Prudente de Moraes. O patriotismo, em Prudente de Moraes atribuído aos "cidadãos" colaboradores do governo, aqui é estendido aos "concidadãos", a quem o governante afirma seu "pensamento" na direção dos "altos destinos" da Nação. A afirmação projeta uma disparidade entre o futuro almejado e o presente vivido. Não sob o modo do conflito presente a ser resolvido, mas sim de uma direção inequívoca para o progresso. É nesta disparidade positiva entre o presente e o futuro desejado que se inscreve a enunciação de "concidadãos"; já a enunciação de "cidadão" se articula ao rememorado de um "cidadão" em particular, determinado como "eminente": o ex-presidente Prudente de Moraes, ao qual o sucessor atribui uma "nobre conduta".

10. Ao assumir o governo da República, cheio de confiança nos poderosos elementos de vitalidade nacional e seguro da dedicação patriótica dos meus concidadãos, cumpre-me expor à Nação, com sinceridade e clareza, todo o meu pensamento na direção dos seus altos destinos.

11. Quero ver também na nobre conduta do eminente cidadão, por uma feliz identificação com os altos interesses nacionais, o suave reflexo da fraternal convivência de outrora.

\subsection{O “espírito de tolerância” de Rodrigues Alves (1902-1906)}

No discurso inaugural de Rodrigues Alves, há três ocorrências de "concidadãos", todas especificadas por "meus" e todas se referindo ao conjunto dos governados. O presidente promete aos seus concidadãos governar com "espírito de tolerância, sem ódios, sem preferências injustas ou odiosas exclusões". A promessa rememora ainda uma vez um estado de conflito não nomeado, ao qual se atribuem "preferências injustas ou odiosas 
exclusões", e no qual seria preciso apelar ao "espírito" do presidente, ainda que, contraditoriamente, este espírito seja alegadamente fundado "nas invariáveis normas da justiça". Se estas normas não variassem, não haveria necessidade de se lançar mão do "espírito do governante"; não haveria tampouco a necessidade de afirmar a intenção de respeitar e fazer respeitar "todos os direitos", ou de afirmar a expectativa de ser "um governo justo", ou a defesa da "firmeza das instituições" e da "grandeza da República". O conflito não nomeado, pela maneira como vai sendo indicado, significa a instabilidade da República e de suas instituições. Aos "concidadãos", o presidente atribui um "espírito de ordem", e às forças armadas, "o seu nunca desmentido patriotismo". O "patriotismo" é também atribuído aos "brasileiros". No discurso de Rodrigues Alves, "concidadãos" se inscreve na afirmação das diferentes qualidades do governante, dos seus concidadãos e das forças armadas como elementos para a "firmeza das instituições" e a "grandeza da República". As esperanças no futuro da Pátria, diferentemente do discurso do seu antecessor, não são projeções positivas, mas sim balizadas pela promessa de respeitar e fazer respeitar o que já não deveria depender de promessa para ser respeitado.

12. Inspirando-me nas invariáveis normas da justiça, respeitando e fazendo respeitar todos os direitos, prometo aos meus concidadãos manter no governo o mais largo espírito de tolerância, sem ódios, sem preferências injustas ou odiosas exclusões.

13. Esperando ser um Governo justo, confio na disciplina dos espíritos, no espírito de ordem dos meus concidadãos, na ação legal das forças armadas e no seu nunca desmentido patriotismo.

14. Dirigindo aos meus concidadãos, neste dia memorável, cordiais saudações com as mais fundadas esperanças no futuro da pátria e cheio de confiança no patriotismo dos brasileiros, afirmo perante Deus que farei tudo quanto de mim depender para a firmeza das instituições e para a grandeza da República. 


\subsection{A educação do espírito dos cidadãos: Afonso Pena (1906 -1909)}

No discurso de posse de Afonso Pena, quarto presidente civil da República, há uma ocorrência de "concidadãos", também especificada por "meus", como nos presidentes civis anteriores, e também se referindo a todos os governados; há ainda duas ocorrências de "cidadãos". A enunciação de "concidadãos" rememora o pleito eleitoral, a "subida honra" que os concidadãos conferiram ao presidente. "Concidadãos" vem reescriturado, em seguida, por "povo brasileiro", de quem o presidente se compromete a promover "o bem estar e a prosperidade". Mais uma vez, se projeta um futuro para os governados, um futuro que indica progresso. Desta vez, não há indicação de conflito na República brasileira. Eis o recorte:

15. Ao assumir a Suprema Magistratura da República, no período presidencial que hoje começa, cumpro o grato dever de significar aos meus concidadãos o meu reconhecimento pela subida honra que me conferiram e à qual procurarei corresponder empregando todas as energias de que sou capaz, na promoção do bem estar e da prosperidade do povo brasileiro.

Na enunciação de "cidadãos", há uma divisão entre uma referência a todos os governados e uma parte destes, os "ilustres e competentes cidadãos" que participaram de um dos Congressos de Instrução ocorridos no Rio de Janeiro. Tanto em um emprego como em outro, o tema é a educação. No recorte acima, observamos a reescritura de "concidadãos" por "povo brasileiro". O procedimento de reescritura continua no recorte 16, com "o povo", "responsável pelos seus destinos", e "os cidadãos", de quem se julga necessário “o esclarecimento e educação do espírito” para o "funcionamento normal das instituições"; estas, por sua vez, são predicadas como "democráticas", e não como republicanas. A palavra "República" aparecerá no recorte seguinte (17), na expressão nominal "capital da República", referindo-se à sede do Congresso de Instrução em que "ilustres e competentes cidadãos" discutiam as questões "mais elevadas e práticas do ensino", cidadãos estes cujas "opiniões autorizadas" servirão de guia para reformas feitas pelo "poder público". "República" é, então, determinada, por "democracia” e é nesta relação que se preconiza a educação do "espírito dos cidadãos" e a presença de "ilustres e competentes cidadãos" que ajudem 
a formular as políticas de ensino. Como no antecessor, não há indicação de conflito presente, mas, diferentemente daquele, aqui as "esperanças no futuro da Pátria" se transformam em projeto político para o "bem-estar e a prosperidade do povo brasileiro", do qual a educação é peça fundamental.

16. Nas democracias, em que o povo é responsável pelos seus destinos, o esclarecimento e educação do espírito dos cidadãos constituem condição elementar para o funcionamento normal das instituições.

17. A reunião, na Capital da República, de um Congresso de Instrução, em que ilustres e competentes cidadãos têm discutido as questões mais elevadas e praticas do ensino, é fato animador e que demonstra quanto a opinião se preocupa com este interessante objeto. A manifestação de opiniões autorizadas na indicação de reformas proveitosas é de inestimável valor para guiar o poder público.

\subsection{O cidadão-soldado de Hermes da Fonseca (1910-1914)}

Hermes da Fonseca, sobrinho de Deodoro da Fonseca, é o terceiro e último presidente militar da República Velha, o único dentre os militares que é eleito pelo voto popular. Em seu discurso de posse, propõe transformar cada "patrício" em "cidadão-soldado". Há, neste discurso, uma ocorrência de "cidadãos", que se refere a todos os governados e distingue a qualificação de "cidadãos" e a de "homens"; há também uma ocorrência de "cidadão-soldado", que se refere aos governados, tal como seriam preparados a partir do governo que inicia; e ainda uma ocorrência de "cidadão", referindo-se ao próprio governante, que se divide neste recorte (20) entre "cidadão" e "soldado". Como para o presidente anterior, a enunciação de "cidadãos", e, no caso do militar, também a de "cidadão-soldado", se inscreve na afirmação da necessidade de formação dos governados; neste caso, a formação é a do "espírito e o coração daqueles que amanhã serão homens e cidadãos", o que envolve o ensino técnico capaz de ser ao mesmo tempo utilitário e também gerador de "instrução de ordem ou cultura secundária"; esta formação é ligada a medidas de composição de um arsenal bélico e à indústria de armamentos, e outro 
aspecto da formação, a partir da qual "cada um de nossos patrícios se transformará em cidadão-soldado".

Por sua vez, a enunciação de "cidadão", referindo-se ao próprio governante, que se autorrefere também como "soldado", se inscreve na afirmação da aspiração da "estabilidade do regime", junto à da "felicidade da pátria" e ao "cumprimento inflexível da lei", a que o governante aspira como "soldado". É no projeto de um país em que a formação seja militar, técnica, e com alguma "instrução de ordem ou cultura secundária” e prepare para a guerra que se inscrevem as enunciações de "cidadãos", "cidadão-soldado" e "cidadão". Nelas, O soldado se sobrepõe ao cidadão, e este ao homem. É na afirmação do ensino utilitarista e da formação de um país preparado para a guerra que se inscreve a enunciação de cidadãos e cidadão-soldado e a afirmação do anseio de promover a estabilidade do regime e a felicidade da pátria.

18. Particular atenção dedicarei ao ensino técnico profissional, artístico, industrial e agrícola que, ao par da parte propriamente prática e imediatamente utilitária, proporcione também instrução de ordem ou cultura secundária, capaz de formar o espírito e o coração daqueles que amanhã serão homens e cidadãos.

19. Estou certo de que, no limite das dotações orçamentárias, estabelecendo-se verbas parceladas e convenientes, poderemos, em poucos anos, pelo desenvolvimento paulatino de arsenais e fábricas, aquisição de armamentos e material bélico, constituídas as unidades táticas que pela reforma foram criadas, formar uma nação militarmente forte, sem que haja necessidade de se manterem os nosso quartéis repletos de soldados, pois que, pelos processos adotados, cada um dos nossos patrícios se transformará em cidadão-soldado.

20. E ser-me-á fácil a tarefa porque, soldado, só tenho uma aspiração - o cumprimento inflexível da lei; cidadão, só tenho um ideal a estabilidade do regime e a felicidade da pátria. 


\subsection{O sacrifício de Epitácio Pessoa (1919-1922)}

Entre Hermes da Fonseca e Epitácio Pessoa, governou o Brasil Venceslau Brás (1914-1918). No seu discurso, não há ocorrências de "cidadão" ou de seus derivados. É a primeira quebra na presença dessas palavras (ou pelo menos de uma delas), quebra esta que volta a acontecer após Epitácio Pessoa, nos discursos de posse dos dois últimos presidentes da República Velha: Artur Bernardes (1922-1926) e Washington Luís (19261930).

No discurso de Epitácio Pessoa, há uma única ocorrência de "concidadãos", especificada por "meus", como em grande parte das ocorrências da palavra nos discursos de posse da Primeira República. A enunciação de "concidadãos" se inscreve no pedido de compreensão de futuras ações do governante em relação ao dinheiro público, o que remete à crise financeira aguda do país. Epitácio Pessoa significa estas ações por ele previstas como um "sacrifício" sobre seus sentimentos. Também significa pelo sentimento os "concidadãos" em sua reescritura por "um só coração brasileiro", expressão nominal à qual se articula a suposição de uma incapacidade de "por o seu interesse próprio acima do interesse vital da nossa Pátria". Temos, então, a reescritura de "concidadãos" por "Pátria"; e, no final do recorte, por "nação" em "a honra da nação". A crise indicada divide o presidente entre o "querer" e o "poder" e o que se pode está ligado ao "interesse da Pátria", determinado por "conveniências supremas do crédito público". É esta cadeia de relações que determina "a honra da Nação" e na qual se inscreve a enunciação de "meus concidadãos".

21. Tenho, pois, o direito de esperar que todos os meus concidadãos, a quem este assumpto atinge, compreendam o sacrifício que acaso eu tenha de fazer sobre os meus sentimentos, para não faltar ao dever imposto pelas grandes responsabilidades do meu cargo. A questão não é só de querer, é também de poder, e eu não creio que haja um só coração de brasileiro, capaz de por o seu interesse próprio acima do interesse vital da nossa Pátria. O Congresso, que apenas inicia o estudo da receita geral, examinará essas reclamações, o seu número, a extensão dos compromissos que elas criam para o Tesouro, a situação particular de cada classe ou dos seus membros e verá se é possível atendermos, e até que 
ponto, a interesses tão dignos de respeito, sem prejuízo das conveniências supremas do crédito público em que envolve a honra da Nação.

\subsection{De concidadãos a cidadãos}

Entre Deodoro da Fonseca e Epitácio Pessoa, observamos as ocorrências, por vezes no mesmo acontecimento enunciativo, de duas palavras que funcionam sempre como substantivos: cidadão/cidadãos e concidadãos. Quantitativamente, há uma prevalência de concidadãos sobre cidadão/ cidadãos. A palavra só não está presente nos discursos de posse dos militares Floriano Peixoto e Hermes da Fonseca. À exceção do discurso de Deodoro, em que é empregada como vocativo em quase todas as ocorrências, na enunciação dos outros cinco presidentes, a palavra vem especificada por "meus". No conjunto de discursos de posse analisados, concidadãos ocorre sempre no plural e, seja como vocativo, seja precedida por "meus", à exceção de uma ocorrência em Deodoro - "os nossos concidadãos residentes nas províncias" - sempre se refere ao conjunto dos governados. Em todos os casos, ela se inscreve como signo da igualdade entre o governante e os governados, apagando a diferença que o próprio lugar de locutor-governante em um sistema representativo faz significar.

Já em relação a cidadão(s), temos um emprego genérico que refere o conjunto dos brasileiros tanto no singular quanto no plural, e um emprego particular referindo um indivíduo (no singular) ou um grupo especificado (no plural). No singular, o emprego particular diz respeito à referência a si mesmo pelo presidente, no discurso de Hermes da Fonseca, e ao antecessor, Prudente de Moraes, no discurso de Campos Sales. No plural, o emprego particular refere os "abaixo-assinados", em Deodoro; os "de diversas classes", em Floriano; aqueles “dos mais ilustrados e competentes", em Moraes, e "ilustres e competentes", em Pena. O emprego genérico do singular cidadão se dá no nome composto cidadão-soldado, enunciado por Hermes da Fonseca, uma projeção sobre cada brasileiro em formação, que deverá se tornar cidadão-soldado. Já a forma plural cidadãos é empregada referindo-se a todos os governados; em Deodoro, no sintagma "liberdade e os direitos dos cidadãos", em Pena, em "o esclarecimento e educação do espírito dos cidadãos", e em Fonseca "homens e cidadãos". 
De um lado, observamos que a forma mais frequente para o emprego genérico é concidadãos. De outro, observamos entre as três formas - concidadãos/ cidadão/cidadãos, um jogo contraditório entre a igualdade e a diferença entre governantes e governados e dentro destas duas categorias, que, no movimento de reescrituras e articulações, destaca do conjunto certas categorias sociais: o exército, as Forças Armadas, os funcionários públicos, os residentes nas províncias, os que colaboram com o governo, os pertencentes a diversas classes atuantes na luta armada, o Congresso Nacional, da Suprema Magistratura da República, os governantes anteriores.

Neste jogo de aproximações e distinções, de um lado, há a relação entre as formas concidadãos/cidadão/cidadãos e as outras que referem seja o todo dos governantes e governados, seja uma dessas categorias, ou parte delas. De outro lado, há modos de caracterização do governante e dos governados, e há um modo de caracterização do "brasileiro", ou do "povo brasileiro" ou da "nação", que vai se especificando, a partir do discurso de Floriano Peixoto, pela afirmação da Pátria/do patriotismo. Este, que em Deodoro é atribuído à "revolução", a partir de Floriano, passa a predicar as formas que referem os governados, ou parte deles, ou ainda o governante. Junto ao patriotismo e à afirmação da Pátria como sentidos dominantes, vai sendo afirmado um "espírito" ou "coração" que, no caso dos governados, ora são enunciados como realidades prontas, ora a serem formadas pela educação provida pelo Estado, e, no caso dos governantes, se ligam à responsabilidade pela manutenção e/ou progresso da República.

Assim, com as disparidades construídas sob o efeito de aproximação entre governante e governados pelo signo concidadãos, das quais faz parte a caracterização díspar de um e de outros, a distribuição de papeis entre eles vai configurando um modo de significar a República. As ações atribuídas aos governados como um todo se restringem às já realizadas: a deposição do regime monárquico em Deodoro, a luta armada que resulta na renúncia de Deodoro, (promovida não pelo conjunto dos cidadãos, mas por “cidadãos de diversas classes") em Floriano, e a eleição do governante, mencionada por Prudente de Moraes e Epitácio Pessoa, aos governados cabem não ações, mas posturas como "compreensão", "cooperação", "dedicação" patrióticas.

Os lugares em que se vislumbra um projeto de "brasileiro" ao se enunciar o(s) cidadão(s)/concidadãos do país como um conjunto estão em Afonso Pena e Hermes da Fonseca, e, em ambos, este projeto se articula à educação. 
Afonso Pena, que liga democracia e República ao se dirigir aos "cidadãos", afirma que "o povo é responsável pelos seus destinos" e atribui ao Estado "o esclarecimento e educação do espírito dos cidadãos", "condição elementar para o funcionamento normal das instituições". A educação em Hermes da Fonseca deve ser "capaz de formar o espírito e o coração daqueles que amanhã serão homens e cidadãos" e se constituirão em cidadãos-soldados, assim como o é o próprio presidente, que aspira, como soldado, “o cumprimento inflexível da lei"; como cidadão, "a estabilidade do regime e a felicidade da pátria". Vê-se, entre um e outro presidente, nestas indicações de projetos para o brasileiro pela educação, diferentes enfoques - o ensino técnico e militarista em Hermes da Fonseca, e, em Afonso Pena, a educação esclarecedora dos espíritos para que os brasileiros possam exercer a responsabilidade pelos seus destinos enquanto cidadãos de uma república democrática. Estes diferentes projetos de educação se sustentam, evidentemente, em diferentes projetos de República.

Outro modo pelo qual os governantes significam - ainda que de modo indicativo, e não definidor - seus projetos de República ao se dirigir aos governados como cidadão(s) ou concidadãos é na determinação dos temas de cada recorte e no modo como se dá a relação de articulação e/ou de reescritura às palavras que inscrevem estes temas e nossas palavras-objeto, predicando-as e produzindo discursos sobre a República. Se há, ligado ao discurso patriótico, um discurso positivista, que rememora a disciplina, a ordem, o progresso por diferentes caminhos que nossos recortes são insuficientes para percorrer em detalhe, os temas dos recortes e os discursos produzidos sobre eles dão visibilidade à complexidade dos discursos produzidos e a algumas diferenças entre eles.

Temos, então, em Deodoro da Fonseca, o tema da proclamação da República, que vai se inscrevendo em um discurso de revolução pacífica e apoiada por todo o povo, e de continuidade. Rememoram-se as diferentes categorias participantes da proclamação ("o povo, o exército e a armada nacional, em perfeita comunhão de sentimentos com os nossos concidadãos residentes nas províncias"), afirma-se o "governo da paz, da liberdade, da fraternidade e da ordem", que manterá os "direitos adquiridos por cada funcionário" e acatará "todos os compromissos nacionais contraídos durante o regime anterior, os tratados subsistentes com as potencias estrangeiras, a dívida pública externa e interna, os contratos vigentes e mais obrigações legalmente estatuídas". 
Em Floriano Peixoto, o tema é a luta armada que o levou ao poder. O discurso pacifista é substituído pelo discurso de exaltação da luta armada. Em Prudente de Moraes, o tema é a primeira eleição da República e o discurso produzido é o de valorização do novo momento da República, a partir do "pleito eleitoral mais notável da vida nacional". Campos Sales produz um discurso progressista, visando aos "altos destinos" da nação. Rodrigues Alves tematiza os direitos garantidos pelo regime e produz um discurso de valorização das leis, comprometendo-se em ser justo. Afonso Pena tematiza a democracia e produz um discurso de valorização da educação para a vivência democrática. Hermes da Fonseca tematiza o ensino e a formação de um país preparado para a guerra. O discurso militarista enfoca a transformação de todo patrício em um “cidadão-soldado". Epitácio Pessoa tematiza as dificuldades financeiras do país e produz um discurso moralista de honra aos compromissos e de sacrifícios.

\section{Palavras Republicanas na Primeira República Brasileira}

Nos perguntamos como significa, nos acontecimentos dos discursos de posse dos presidentes da Primeira República, a enunciação de cidadão(s) e concidadãos. Procuramos compreender de que modo por meio dessas palavras se afirma a relação entre governante e governados, e o pertencimento do governo que se inicia ao regime republicano.

Procuramos responder a esta questão pela análise dos movimentos de reescritura e articulação às palavras analisadas, em primeiro lugar, observando de maneira mais detalhada os movimentos textuais de cada um dos recortes dos discursos de posse dos oito presidentes da Primeira República em que nossas palavras-objeto são enunciadas. A partir daí, pudemos descrever o funcionamento morfossintático e semântico-enunciativo dessas formas e observamos que a forma mais frequente para o emprego genérico, isto é, referindo-se ao conjunto dos governados, neste conjunto de textos, é concidadãos, forma esta pela qual se produz um efeito de igualdade entre governante e governados. Por outro lado, entre as três formas - concidadãos/cidadão/cidadãos, observamos um jogo contraditório entre a igualdade e a diferença entre governantes e governados e dentro destas duas categorias, pelo qual algumas categorias sociais se destacam do conjunto de cidadãos/concidadãos, se constituindo pela diferença em relação ao todo. 
Em segundo lugar, procuramos responder à nossa questão seguindo alguns fios semânticos da tessitura textual dos discursos de posse, nos recortes em que nossas palavras-objeto aparecem: a construção de uma associação entre o brasileiro/a nação e a Pátria/o sentimento patriótico; a distribuição de papeis entre governante e governados, em que se constata de modo quase absoluto a atribuição de passividade a estes últimos no processo de constituição da República; as poucas indicações (apenas duas) de um projeto de brasileiro, ambas associadas à educação e com diferenças importantes entre si; e, finalmente, os temas dos recortes analisados e o modo como produzem discursos sobre a República, em que vimos, na relação com o discurso positivista e o patriótico, deslizes de sentido entre uns presidentes e outros, que vão do pacifismo ao belicismo, da continuidade ao progressismo, passando pelo legalismo ou pelo moralismo. E isto em uma breve análise pontual sobre apenas uma parte dos discursos de posse.

O que pudemos observar são diferentes ênfases no modo de significar a República ao enunciar os nomes cidadão(s)/concidadãos, ou, em sentido inverso, diferentes sentidos para os nomes cidadão(s)/concidadãos nos modos de significar a República. Esta pequena análise nos mostra que a instabilidade dessas palavras-chave no processo republicano se deve não apenas aos longos períodos de ditadura que vivemos no último século, mas, pelo menos neste primeiro momento da República, à falta de um projeto republicano de Estado e de mecanismos que garantissem sua manutenção a despeito das mudanças de governo. A instabilidade dessas palavras é uma especificidade da nossa República; sendo assim, investigar as particularidades dos seus sentidos na enunciação dos diferentes governantes nos permitirá compreender o modo como, por meio delas, cada governo afirma seu pertencimento ao regime republicano, e o modo como, a seu passo, elas vão se movimento semanticamente entre a instabilidade e a estabilidade. Este trabalho oferece uma primeira contribuição nesta direção.

\section{Referências}

ELIAS DE OLIVEIRA, S. Cidadania: história e política de uma palavra. Campinas: Pontes; RG, 2006. 
GUIMARÃES, E. Os sentidos do cidadão no Império e na República no Brasil. In: GUIMARÃES, E.; ORLANDI, E. P. (Orgs.). Lingua e cidadania: o português no Brasil. Campinas: Pontes, 1996. p. 39-46.

GUIMARÃES, E. Semântica do acontecimento. Campinas: Pontes, 2002.

GUIMARÃES, E. Domínio semântico de determinação. In:

GUIMARÃES, E.; MOLLICA, M. C. (Orgs.). A palavra: forma e sentido. Campinas: Pontes, 2007.

GUIMARÃES, E. Análise de texto: procedimentos, análises, ensino. Campinas: RG, 2011.

INDURSKY, F. O cidadão na III República Brasileira. In: GUIMARÃES, E.; ORLANDI, E. P. (Orgs.) Lingua e cidadania: o português no Brasil. Campinas: Pontes, 1996. p. 47-55.

ORLANDI, E. P. Interpretação: autoria, leitura e efeitos do trabalho simbólico. São Paulo: Vozes, 1996.

PECHEUX, M. Semântica e discurso: uma crítica à afirmação do óbvio. 2. ed. Campinas: Editora da UNICAMP, 1995 [1975]. 